\title{
Effect of Water and Nitrogen, and Grazing on Nematodes in a Shortgrass Prairie
}

\author{
JAMES D. SMOLIK AND JERROLD L. DODD
}

\section{Abstract}

Densities of plant feeding nematodes were highest in range receiving additional water and nitrogen $\left(\mathrm{H}_{2} \mathrm{O}+\mathrm{N}\right)$, however, biomass of plant feeders was not significantly increased. Populations of stunt nematodes were highest in the grazed treatment. Maximum numbers of 3 other plant feeding groups, ring, Tylenchidae and Dorylaimida, occurred in the $\mathrm{H}_{2} \mathrm{O}+\mathrm{N}$ treatment. Predaceous and microbial feeding nematode populations were also highest in the $\mathrm{H}_{2} \mathrm{O}+\mathrm{N}$ treatment. Populations of plant feeding and predaceous nematodes peaked in early June and remained high throughout the growing season. Populations of microbial feeders also peaked in early June, but fluctuated through the sampling period. It appears the benerits of additional water and nitrogen on plant growth are not offset by large increases in biomass of plant feeding nematodes.

Nematodes are major consumers in the shortgrass prairie (Scott et al. 1979). They are also prevalent in other North American grasslands (Norton and Schmitt 1978, Freckman et al. 1979, Smolik and Lewis 1982). Cattle grazing and wildfire did not affect nematodes in a shrub steppe community (Smolik and Rogers 1976); however, in a mixed prairie in South Dakota plant feeding nematode biomass was decreased by heavy cattle grazing (Smolik and Lewis 1982). The objectives of the present study were to determine the vertical distribution of nematodes and effects of grazing, seasonality, and application of water and nitrogen on nematode populations in the shortgrass prairie. Additionally, results of this and an earlier study in a mixed prairie (Smolik and Lewis 1982) are also discussed.

\section{Materials and Methods}

This study was conducted in a shortgrass prairie of northcentral Colorado. Climatic and edaphic characteristics have been described by Dodd and Lauenroth (1979). Vegetation in the study area was dominated by Bouteloua gracilis, Opuntia polycantha, and Artemisia frigida. In 1973 samples were obtained in mid-August from areas ungrazed since 1939 and from areas grazed heavily (ca. $1 \mathrm{AUM} / \mathrm{ha}$ ) in summer and from another ungrazed area receiving additional water and nitrogen (Dodd and Lauenroth 1979). The water treatment maintained soil water at field capacity for the entire growing season, and annual spring applications of ammonium nitrate maintained soil mineral nitrogen levels at $100 \mathrm{~kg} / \mathrm{ha}$ above adjacent nonfertilized areas. Six randomly selected cores were removed from each area to a depth of $60 \mathrm{~cm}$, subdivided into 6 $10-\mathrm{cm}$ increments, labeled and placed in plastic bags. Samples were placed under ice in an insulated container and shipped to the senior author for nematode analyses. Nematodes were extracted, counted, and biomass determined as previously described by Smolik and Lewis (1982), except an additional taxonomic group (Criconemoides) was included. In 1974 soil cores were removed only from the water plus nitrogen $\left(\mathrm{H}_{2} \mathrm{O}+\mathrm{N}\right)$ treatment on 7 dates in an attempt to measure seasonal effects on nematode populations.

\footnotetext{
Authors are associate professors, Plant Science Department, South Dakota State University, Brookings 57007 , and Range Management Division, University of Wyoming, Laramie 82077. This is Contribution No. 1768, South Dakota Agricultural Experiment Station.

Manuscript received October 12, 1982.
}

\section{Results and Discussion}

\section{Range Treatments}

The taxonomic groupings, genera or species within each group, individual weights, common name, and tropic levels are listed in Table 1. The analyses of variance for 1973 and 1974 data are summarized in Table 2. Significant main effect or interaction means were compared with Fisher's least significant difference (FLSD's) at the .05 level (Carmer and Swanson 1971).

Total plant feeding nematode densities were highest in the $\mathrm{H}_{2} \mathrm{O}+$ $\mathrm{N}$ treatment (Table 3 ). The taxonomic groups comprising the plant feeders varied in their response to the range treatments. Highest populations of Tylenchidae and ring nematodes (Table 3) and plant feeding Dorylaimida (Fig. 1) occurred in the $\mathrm{H}_{2} \mathrm{O}+\mathrm{N}$ treatment, while populations of stunt nematodes were highest in the grazed treatment. Biomass of total plant feeders (Table 3) and populations of the remaining plant feeding groups were not significantly different between treatments (Table 2). The Tylenchidae were primarily responsible for the increase in plant feeder densities in the $\mathrm{H}_{2} \mathrm{O}+\mathrm{N}$ treatment (Table 3); however, they are comparatively small nematodes (Table 1) and they did not significantly increase biomass estimates. In addition, numbers of the larger stunt nematodes declined in the $\mathrm{H}_{2} \mathrm{O}+\mathrm{N}$ treatment.

The majority of the plant feeders occurred in the 0-10 and 10-20 cm sampling depths (Table 4 and Fig. 1), which was similar to their distribution in a mixed prairie (Smolik and Lewis 1982). The lack of a significant increase in plant feeding nematode biomass in the $\mathrm{H}_{2} \mathrm{O}+\mathrm{N}$ treatment (Table 3) would seem to indicate that the treatment benefits are not offset by large increases in the nematode populations. However, nematode biomass estimates fluctuate considerably both between years and among dates within years (Smolik and Lewis 1982). More extensive sampling might have detected consistent differences. In addition, nematodes respond differentially to applications of water and fertilizer as Wallace (1963) indicates and as evidenced by the significant increase in ring nematodes (Table 3). It is possible that a longer duration study would have resulted in certain groups dominating in the $\mathrm{H}_{2} \mathrm{O}+\mathrm{N}$ treatment.

Highest populations of predaceous and microbial feeding nematodes occurred in the $\mathrm{H}_{2} \mathrm{O}+\mathrm{N}$ treatment (Fig. 2 and 3). The majority of both groups occurred in the $0-10 \mathrm{~cm}$ sampling depth. However, the decline in numbers of predators with increasing sampling depth was less than that for microbial feeders. Similar results were observed in the mixed prairie study (Smolik and Lewis 1982).

\section{Seasonal Dynamies}

Maximum populations of total plant feeders occurred in early June and slowly declined during the remainder of the sampling period (Fig. 4). As in 1973 the majority of plant feeders occurred in the $0-10$ and $10-20 \mathrm{~cm}$ sampling depths (Fig. 4). Peak plant feeding nematode biomass occurred in early July (Fig. 5) and ranged from 108 to $216 \mathrm{mg} / \mathrm{m}^{2}$ through the sampling period.

Highest populations of stunt nematodes were recorded in late July (Fig. 6). Spiral nematode populations were highest from May through early July (Fig. 7). The majority of stunt nematodes occurred in the $0-10 \mathrm{~cm}$ sampling depth (Fig. 6) whereas spiral nematode numbers were highest in $10-20 \mathrm{~cm}$ or deeper sampling 
Table 1. Trophle levels, taxonomic grouping, and weights used in comparisons of nematode denaities and blomass.

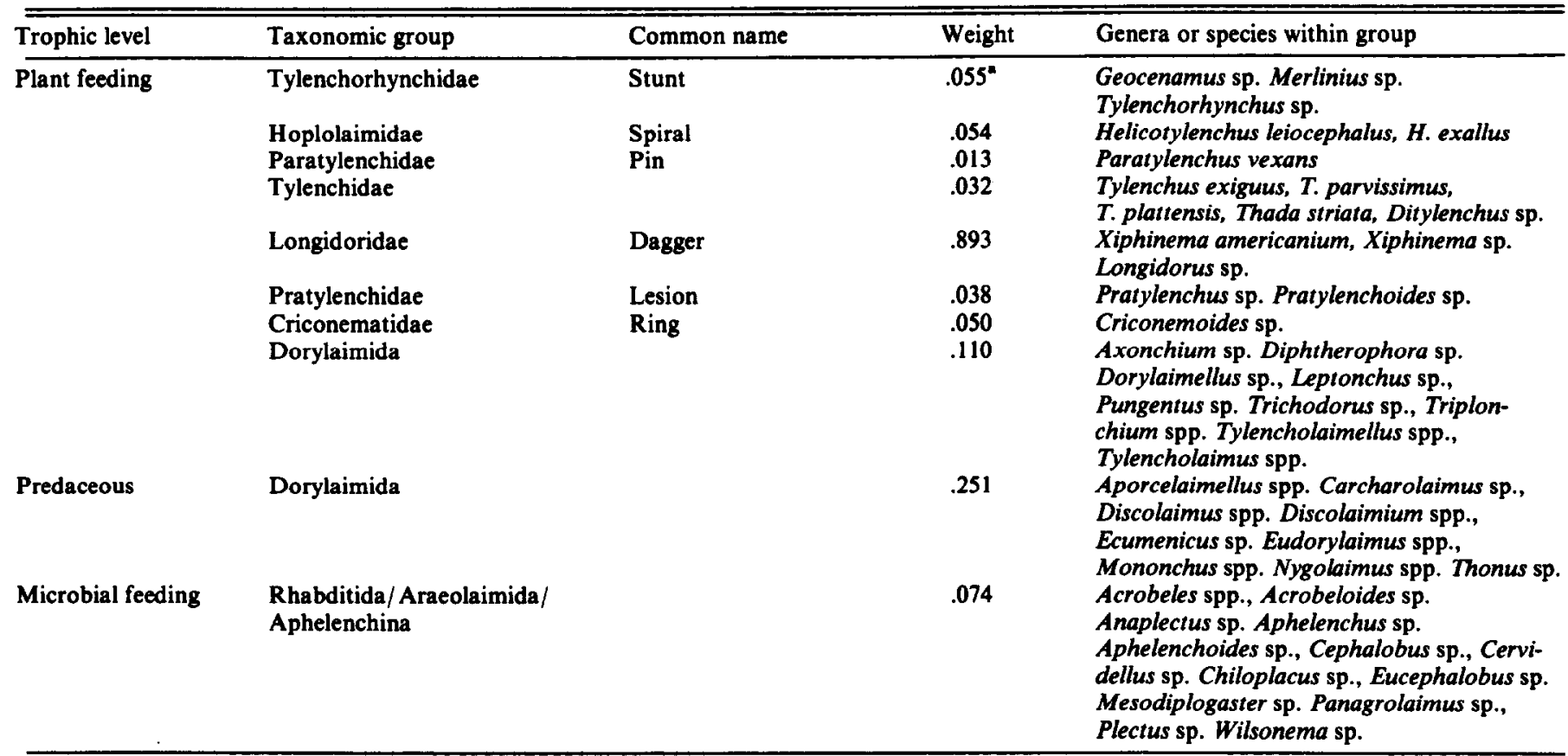

'Average dry weight $(\mu \mathrm{g})$ of an adult nematode within taxonomic group.

Table 2. Summary of significance in analyses of variance of nematode density and biomass data, 1973 and 1974.

\begin{tabular}{|c|c|c|c|c|c|c|c|c|c|c|c|c|c|}
\hline & & Stunt & Spiral & Pin & $\begin{array}{l}\text { Tylen- } \\
\text { chidae }\end{array}$ & Dagger & Lesion & Ring & $\begin{array}{c}\text { Dorylaimida } \\
\text { (plant } \\
\text { feeding } \\
\text { excl. } \\
\text { Dagger) }\end{array}$ & $\begin{array}{l}\text { Preda- } \\
\text { ceous }\end{array}$ & $\begin{array}{c}\text { Micro- } \\
\text { bial } \\
\text { feeding }\end{array}$ & $\begin{array}{l}\text { Plant } \\
\text { feeding }\end{array}$ & $\begin{array}{c}\text { Biomass } \\
\text { plant } \\
\text { feeding }\end{array}$ \\
\hline \multicolumn{14}{|c|}{ Probability of $F$} \\
\hline 1973 & $\begin{array}{l}\text { Range } \\
\text { Treat- } \\
\text { ment }\end{array}$ & .0322 & .0763 & .3615 & .0407 & .4824 & .2557 & .0049 & .0028 & .0029 & .0012 & .0323 & .1448 \\
\hline & $\begin{array}{l}\text { Depth } \\
\text { Treat } \times \\
\text { Depth }\end{array}$ & $\begin{array}{l}.0156 \\
.0655\end{array}$ & $\begin{array}{l}.0536 \\
.5179\end{array}$ & $\begin{array}{l}.0001 \\
.9281\end{array}$ & $\begin{array}{l}.0001 \\
.1226\end{array}$ & $\begin{array}{l}.0201 \\
.5274\end{array}$ & $\begin{array}{l}.0278 \\
.0777\end{array}$ & $\begin{array}{l}.0016 \\
.0001\end{array}$ & $\begin{array}{l}.0001 \\
.0016\end{array}$ & $\begin{array}{l}.0001 \\
.0009\end{array}$ & $\begin{array}{l}.0001 \\
.0014\end{array}$ & $\begin{array}{l}.0001 \\
.2365\end{array}$ & $\begin{array}{l}.0001 \\
.2868\end{array}$ \\
\hline 1974 & $\begin{array}{l}\text { Date } \\
\text { Depth } \\
\text { Date } X \\
\text { Depth }\end{array}$ & $\begin{array}{l}.1025 \\
.0001 \\
.0077\end{array}$ & $\begin{array}{l}.0016 \\
.0001 \\
.0002\end{array}$ & $\begin{array}{l}.0331 \\
.0001 \\
.1883\end{array}$ & $\begin{array}{l}.0001 \\
.0224 \\
.0048\end{array}$ & $\begin{array}{l}.5614 \\
.0001 \\
.1478\end{array}$ & $\begin{array}{l}.0828 \\
.0001 \\
.0072\end{array}$ & $\begin{array}{l}.0269 \\
.0001 \\
.0001\end{array}$ & $\begin{array}{l}.0430 \\
.0001 \\
.0314\end{array}$ & $\begin{array}{l}.0369 \\
.0001 \\
.0255\end{array}$ & $\begin{array}{l}.0037 \\
.0001 \\
.0001\end{array}$ & $\begin{array}{l}.0001 \\
.0001 \\
.0001\end{array}$ & $\begin{array}{l}.0941 \\
.0001 \\
.0243\end{array}$ \\
\hline
\end{tabular}

Table 3. Effect of range treatments on density of total plant feeders, stunt, Tylenchidae, ring nematodes, and biomass of plant feeders in a shortgrass prairie, N.E. Colorado, 1973.

\begin{tabular}{lccccc}
\hline \hline Treatment & Total plant feeders & Stunt & Tylenchidae & Ring & Biomass, plant feeders \\
\hline Ungrazed & $1,767,000^{\circ}$ & 122,000 & 410,000 & 0 & $138^{b}$ \\
Grazed & $3,480,000$ & 315,000 & 594,000 & 0 & 195 \\
H $+\mathrm{N}$ & $4,244,000$ & 137,000 & $1,590,000$ & 128,000 & 12,300 \\
FLSD (.05) & 251,000 & 25,000 & 157,500 & NS & 242 \\
\hline
\end{tabular}

Number of nematodes $/ \mathrm{m}^{2}$ to $60 \mathrm{~cm}$ depth.

${ }^{b} \mathrm{Mg} / \mathrm{m}^{2}$ to $60 \mathrm{~cm}$ depth. 


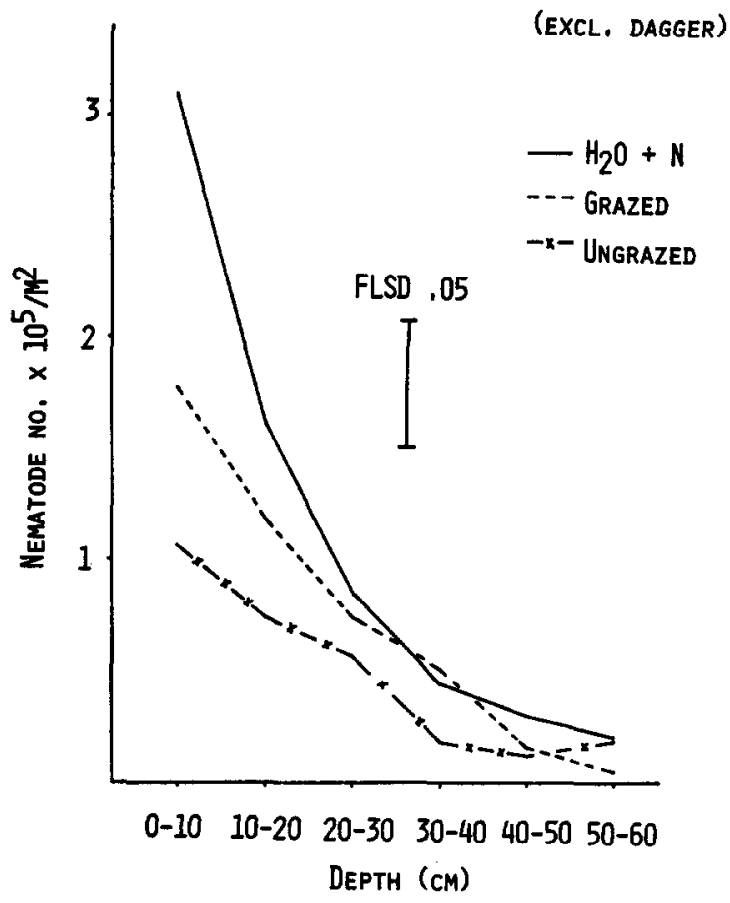

Fis. 1. Vertical distribution of plant feeding Dorylaimida and effect of range treatments, 1973.

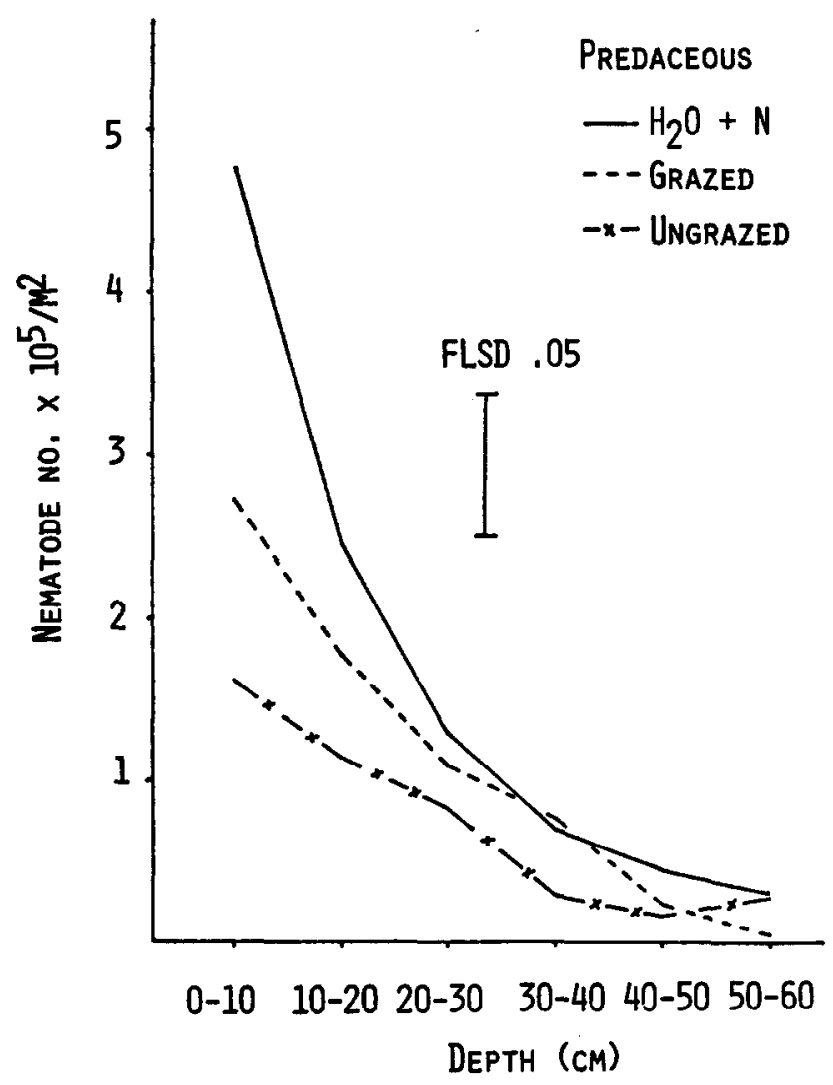

Fig. 2. Vertical distribution of predaceous nematodes and effect of range treatments, 1973.

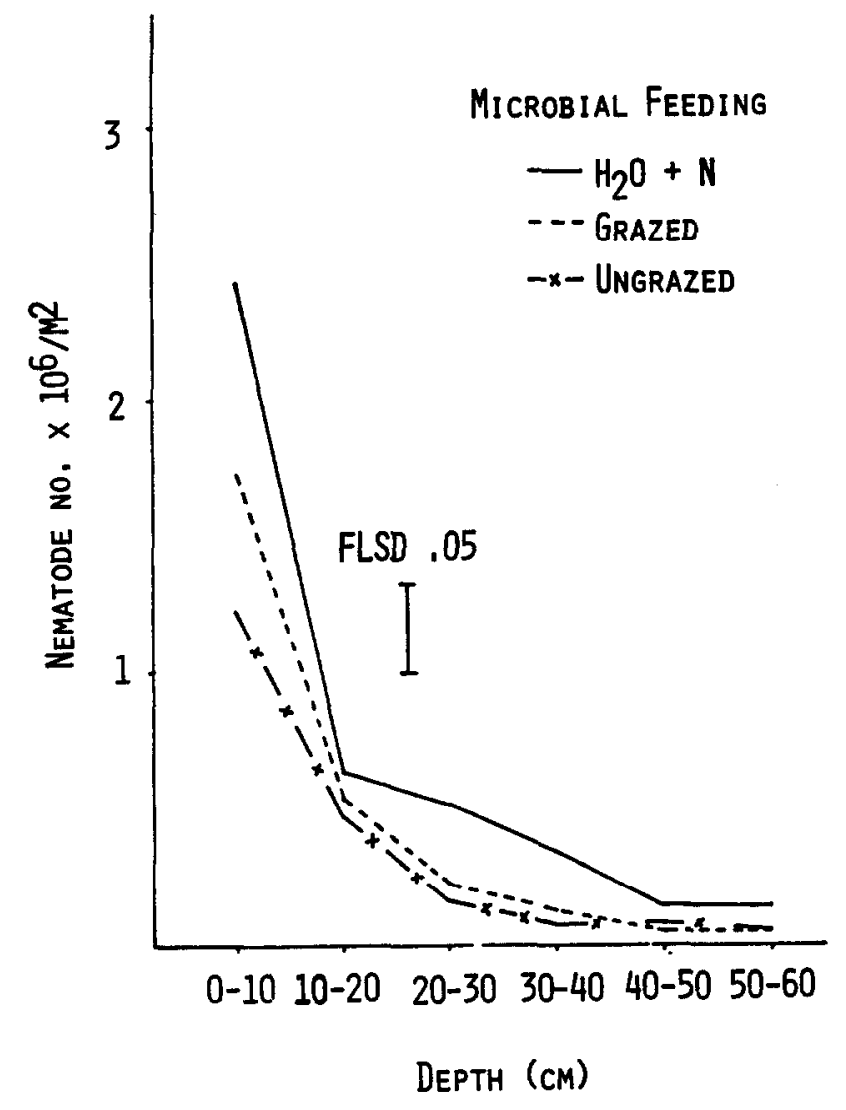

Fig. 3. Vertical distribution of microbial feeding nematodes and effect of range treatments, 1973.

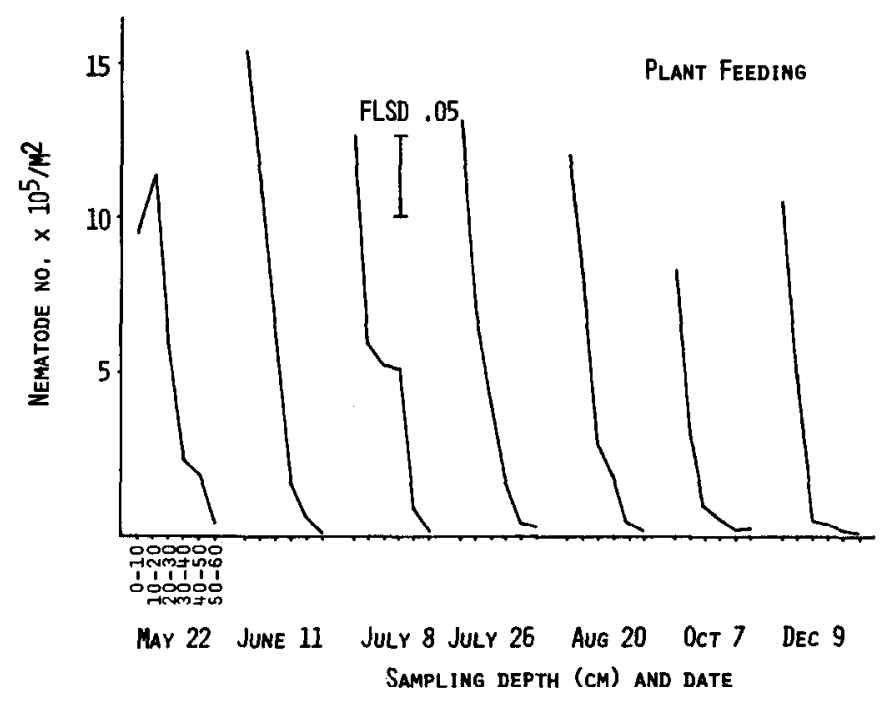

Fig. 4. Seasonal densities of plant feeding nematodes at 6 sampling depths, 1974. 


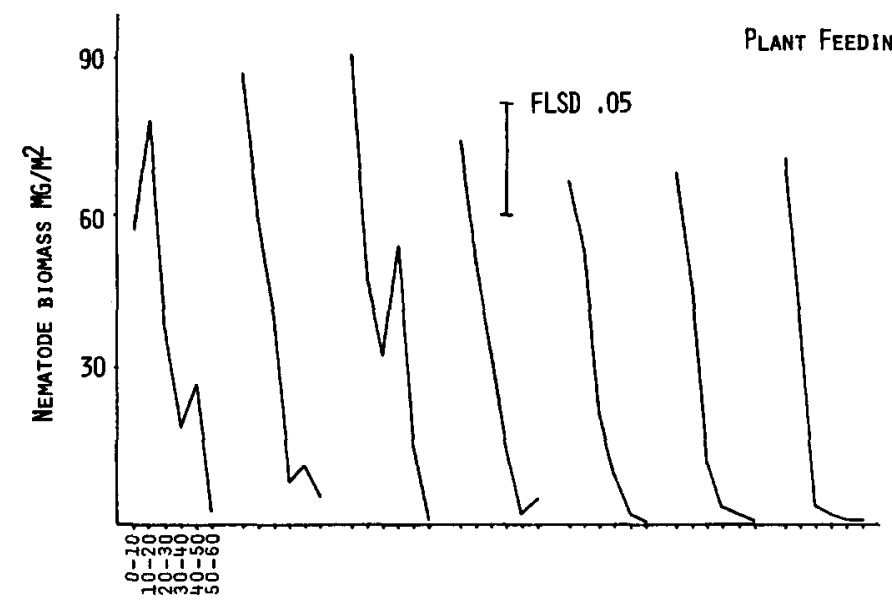

May 22 June 11 July 8 July 26 Aug 20 Oct 7 Dec 9 SAMPLING DePTH (CM) and DATE

Fig.5. Seasonal biomass of plant feeding nematodes at 6 sampling depths, 1974.

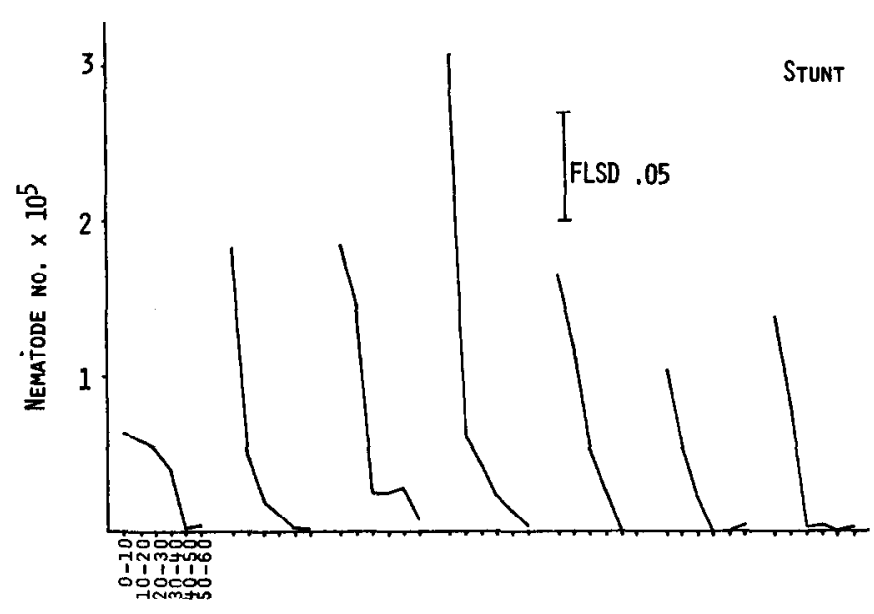

May 22 Jume 11 July 8 July 26 aug 20 OCt 7 Dec 9 SAMPLING DEPTH (CM) aND DATE

Fig. 6. Seasonal densities of stunt nematodes populations at 6 sampling depths, 1974.

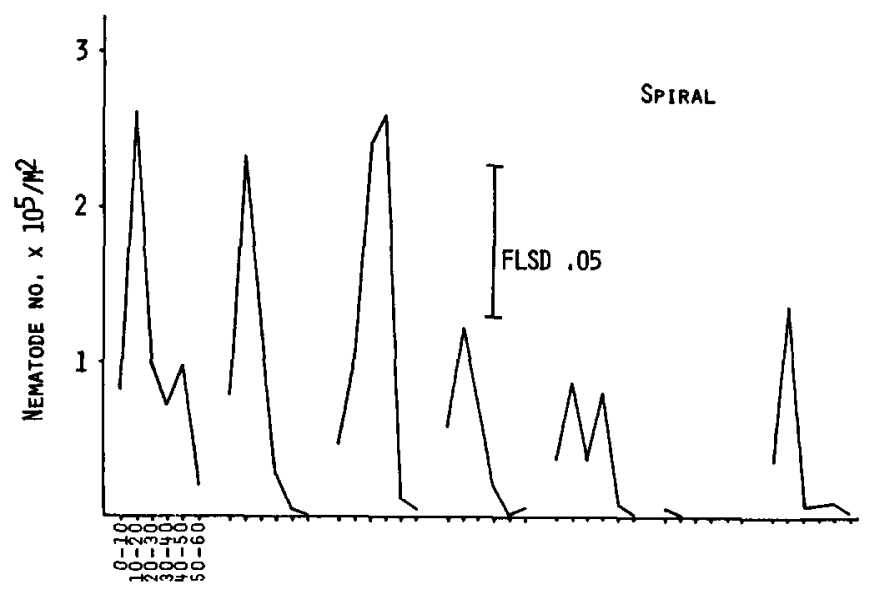

May 22 June 11 July 8 July 26 Aug 20 OCt 7 Dec 9 SAMPLing DEPTh (CM) aNd Date

Fig. 7. Seasonal densities of spiral nematode populations at 6 sampling depths, 1974.

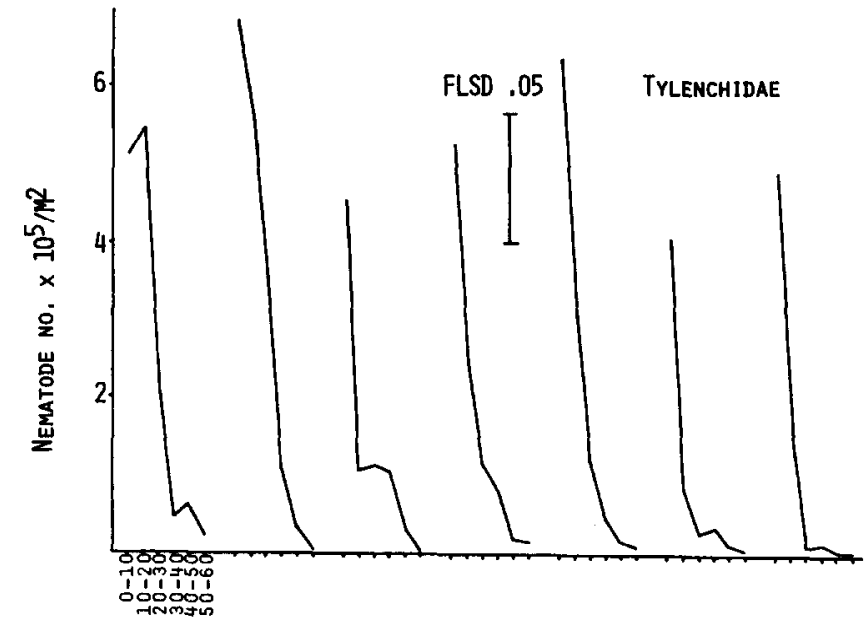

May 22 June 11 July 8 July 26 Aug 20 OCt 7 Dec 9 SAMPLING DEPTH (CM) and DATE

Fig. 8. Seasonal densities of Tylenchidae at six sampling depths, 1974.

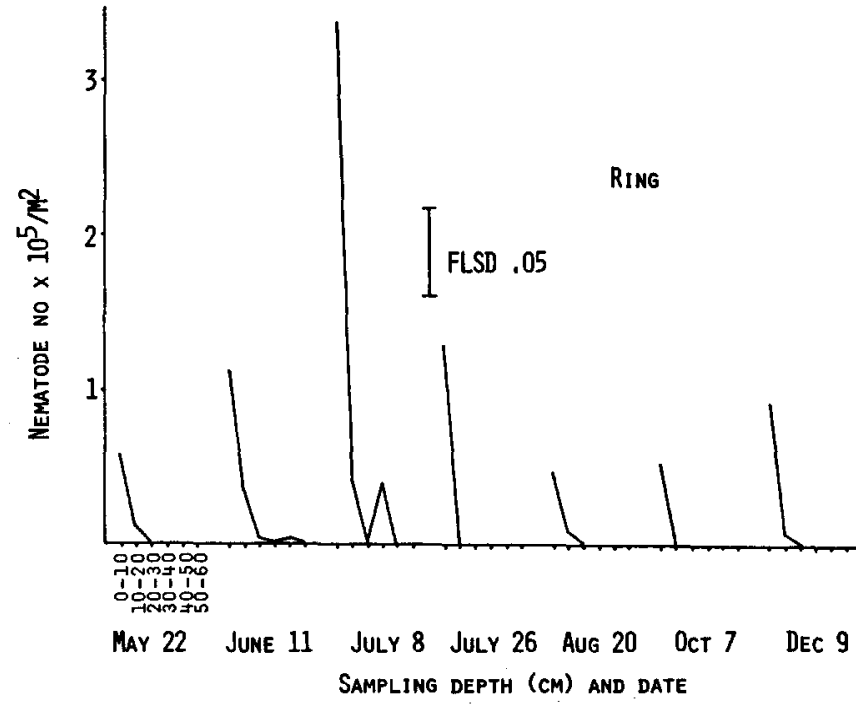

Fig. 9. Seasonal densities of ring nematode populations at 6 sampling depths, 1974.

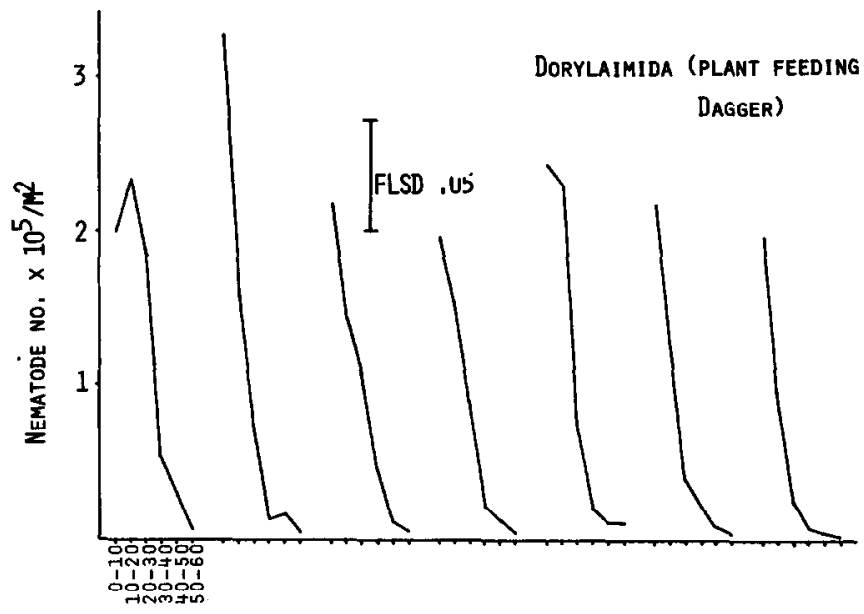

May 22 June 11 July 8 July 26 Aug 20 OCt 7 Dec 9 SAMPLING DEPTH (CM) AND DATE

Fig. 10. Seasonal densities of plant feeding Dorylaimida at 6 sampling depths, 1974. 
Table 4. Vertical distribution of plant feeding nematodes and biomass in a shortgrass prairie, N.E. Colorado, 1973.

\begin{tabular}{|c|c|c|c|c|c|c|c|c|}
\hline $\begin{array}{l}\text { Sampling depth } \\
\text { (cm) }\end{array}$ & $\begin{array}{l}\text { Total plant } \\
\text { feeding }\end{array}$ & Stunt & Pin & Tylenchidae & Dagger & Ring & Lesion & $\begin{array}{l}\text { Biomass, plant } \\
\text { feeding }\end{array}$ \\
\hline $0-10$ & $1,048,600^{*}$ & 100,600 & 138,700 & 374,800 & 5,300 & 35,000 & 4,300 & $70^{\mathrm{b}}$ \\
\hline $10-20$ & 825,500 & 30,300 & 104,100 & 291,200 & 19,500 & 4,300 & 10,300 & 52 \\
\hline $20-30$ & 525,300 & 39,600 & 45,700 & 126,800 & 4,300 & 500 & 4,000 & 26 \\
\hline $30-40$ & 321,100 & 9,500 & 22,600 & 47,100 & 4,000 & 2,900 & 3,000 & 16 \\
\hline $40-50$ & 169,800 & 11,800 & 11,700 & 13,700 & 2,700 & 0 & 0 & 5 \\
\hline $50-60$ & 81,900 & 0 & 7,300 & 10,200 & 2,600 & 0 & 0 & 2 \\
\hline FLSD (.05) & 198,400 & 57,200 & 25,300 & 138,000 & 10,500 & 17,000 & 6,000 & 14 \\
\hline
\end{tabular}

Number/ $\mathrm{m}^{2}$ to indicated depth, average of 3 treatments.

$\mathrm{Mg} / \mathrm{m}^{2}$ to indicated depth.

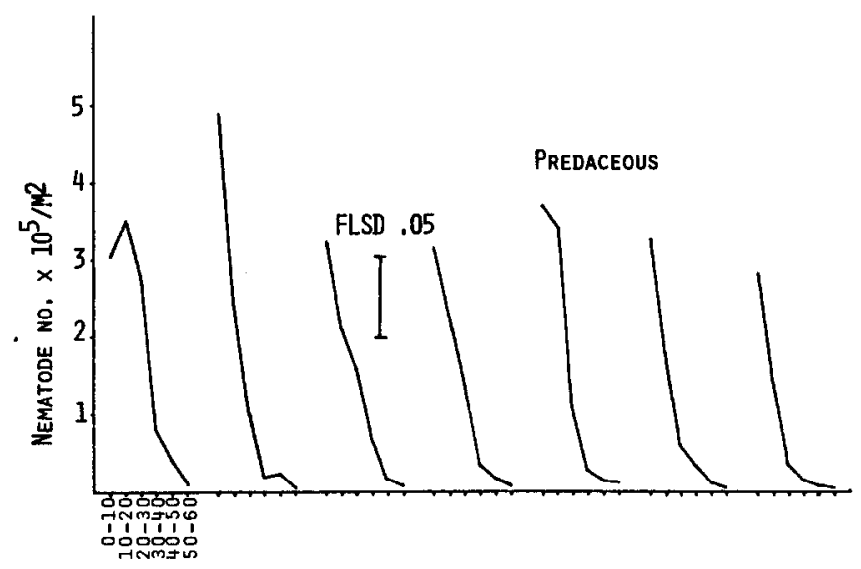

May 22 June 11 July 8 July 26 Aug 20 OCt 7 Dec 9 SAMPLING DEPTH (CM) AND DATE

Fig.11. Seasonal densities of predaceous nematodes at 6 sampling depths, 1974.

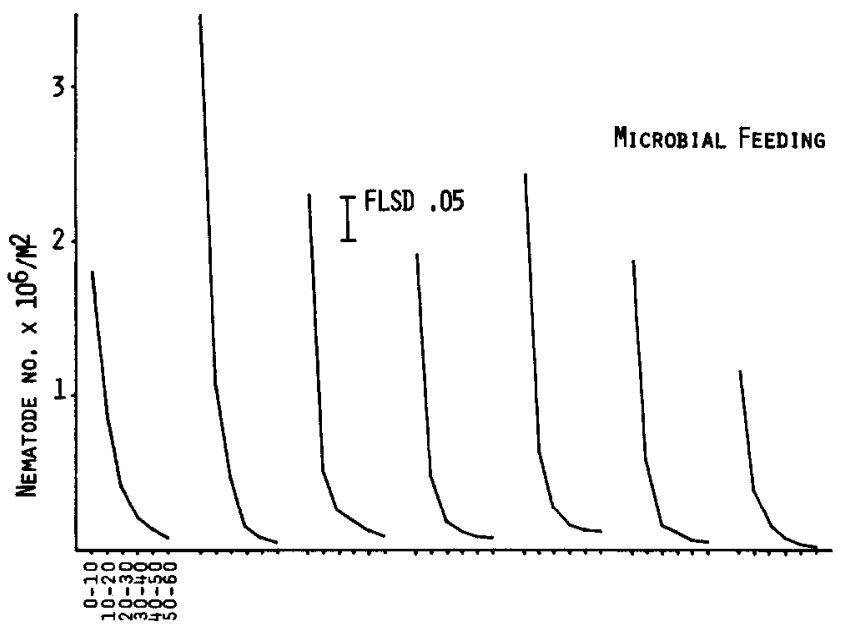

May 22 June 11 July 8 July 26 Aug 20 OCt 7 Dec 9 SAMPLING DEPTH (CM) AND DATE

Fig. 12. Seasonal densities of microbial feeding nematodes at 6 sampling depths, 1974.

depths (Fig. 7). This segregation by depth was also observed in the mixed prairie (Smolik and Lewis 1982) and may suggest a possible means of control through practices such as interseeding or range ripping that disrupt this spatial distribution.

Densities of Tylenchidae were relatively high throughout the sampling period (Fig. 8) with highest populations in early June. Except in late May, highest populations of Tylenchidae occurred in the $0-10 \mathrm{~cm}$ increment (Fig. 8). Pin nematodes reached a peak population of $181,000 / \mathrm{m}^{2}$ in early June. The vertical distribution of pin, lesion, and dagger nematodes was similar to that in 1973 (Table 3). Populations of ring nematodes increased slowly from May to June then climbed sharply in early July and decreased in late July (Fig. 9). The majority of ring nematodes occurred in the 0-10 cm increment. The plant feeding Dorylaimida group contained a comparatively large number of genera (Table 1), which may account for the relatively stable populations throughout the sampling period (Fig. 10).

Populations of predators were highest in early June and fluctuated little for the remainder of the sampling period (Fig. 11). The majority of the predaceous forms occurred in the $0-10$ and $10-20$ $\mathrm{cm}$ increments. Densities of microbial feeders increased significantly from late May to early June, declined in both early and late July, increased again in late August and again declined during the remaining sampling periods (Fig. 12). Interestingly, population fluctuations of the microbial feeders corresponded rather closely to fluctuations in the numbers of soil microarthropods (Dodd and Lauenroth 1979). These two groups may share a similar food base or certain of the microarthropods may prey upon microbial feeding nematodes.

In conclusion, nematode populations are lower and appear to be less sensitive to cattle grazing in the shortgrass region of Colorado than in the mixed prairie of South Dakota. However, vertical distribution of members of all trophic categories was similar in both studies. Additional research should be conducted on the influence of nematodes on energy flow and nutrient cycling patterns in range ecosystems to determine if regulation of nematode populations is a viable method for increasing plant production.

\section{Literature Cited}

Carmer, S.G., and M.R. Swanson. 1971. Detection of differences between means. A Monte Carlo study of five pairwise multiple comparison procedures. Agron. J. 63:940-945.

Dodd, J.L., and W.R. Lauenroth. 1979. Analyses of the response of a grassland ecosystem to stress. p. 43-53. In: Perspectives in Grassland Ecology. N.R. French, ed. Springer-Verlag, New York, N.Y.

Freckman, D.W., D.A. Duncan, and J.R. Larson. 1979. Nematode density and biomass in an annual grassland ecosystem. J. Range Manage. 32:418-422.

Norton, D.C., and D.P. Schmitt. 1978. Community analysis of plant parasitic nematodes in the Kalsow Prairie, Iowa. J. Nematol. 10:171-176.

Scott, J.A., N.R. French, and J.W. Leetham. 1979. Patterns of consumption in grasslands. p. 89-105. In: Perspectives in Grassland Ecology. N.R. French, ed. Springer-Verlag, New York, N.Y.

Smolik, J.D., and L.E. Rogers. 1976. Effects of cattle grazing and wildfire on soil-dwelling nematodes of the shrub-steppe ecosystem. J. Range Manage. 29:304-306.

Smolik, J.D., and J.K. Lewis. 1982. Effect of range condition on density and biomass of nematodes in a mixed prairie ecosystem. J. Range Manage. 35:657-663.

Wallace, H.R. 1963. The Biology of Plant Parasite Nematodes. Edward Arnold Ltd. London p. 212-215. 